\title{
IL9 Gene
}

National Cancer Institute

\section{Source}

National Cancer Institute. IL9 Gene. NCI Thesaurus. Code C28599.

This gene plays a role in inflammatory processes and has been implicated in the pathogenesis of asthma. 